\title{
A controlled trial of prednisone, in low dosage, in patients with chronic airways obstruction
}

\author{
J . A . $\mathrm{EVAN} \mathrm{S}^{1}, \mathrm{I} \cdot \mathrm{M}$. MOR R I O N ${ }^{2}$, \\ a n d K. B. S A U N D E R S ${ }^{3}$ \\ Departments of Medicine and of Thoracic Medicine, St. Thomas' Hospital, London SE1
}

\begin{abstract}
Evans, J. A., Morrison, I. M., and Saunders, K. B. (1974). Thorax, 29, 401-406. A controlled trial of prednisone, in low dosage, in patients with chronic airways obstruction. Ten men with chronic airways obstruction took part in a double-blind controlled crossover trial of $5 \mathrm{mg}$ prednisone, daily for a week, versus placebo.

All patients had breathlessness as their main complaint, and chronic cough with sputum for 2 to 30 years; five had evidence of emphysema on the chest radiograph. None had a personal or family history of asthma. For the group, mean forced expiratory volume in one second was $1 \cdot 11 \mathrm{l}$, and mean forced vital capacity was $2 \cdot 28 \mathrm{l}$. Six patients had abnormally high levels of arterial $\mathrm{PCO}_{2}(46-52 \mathrm{mmHg})$.

When the 'placebo' and 'prednisone' measurements were compared there was no significant change in forced expiratory volumes, bronchodilator effect on forced expiratory volumes, or blood gas tensions. Inspiratory airways resistance measured by body plethysmography was significantly higher, or 'worse', on prednisone (mean $4 \cdot 2 \mathrm{cmH}_{2} \mathrm{O}$ per $1 / \mathrm{sec}$ ) than on placebo (mean $3 \cdot 2$ ).
\end{abstract}

The beneficial effect of corticosteroids in asthma is undoubted. In patients with chronic bronchitis, emphysema, or both, who have chronic airways obstruction with little or no response to inhaled bronchodilator drugs, the effect of corticosteroids is debatable.

Previous studies of this problem have come to widely differing conclusions (see Discussion). The most carefully conducted and controlled studies suggest that prednisone is not helpful.

Despite this evidence, it is common practice to give a trial of steroids to patients with severe dyspnoea not helped by bronchodilators. In the individual case it may be difficult to distinguish a moderate response to prednisone from spontaneous slow fluctuations in the disease. Nevertheless it was our impression that some patients do respond to steroids and also that they may respond to a small dose. We therefore designed a controlled double-blind cross-over trial of prednisone, $5 \mathrm{mg}$ per day by mouth, in patients with chronic airways obstruction and used measurements of forced

Present address:

'University College Hospital, Gower Street, London WC1

'Brompton Hospital, London SW3

s. Department of Medicine, Middlesex Hospital, Mortimer Street, London W1 expiratory lung volumes, airways resistance, and blood gas tensions to assess the effect of the drug.

The patients were asked if they would take part in a trial of a drug which might be beneficial to them, and willingly agreed to participate. The study was approved by the hospital committee on ethical procedures. A short account of this work has been given previously (Evans, Morrison, and Saunders, 1973).

\section{SUBJECTS}

We studied 10 men with chronic diffuse airways obstruction and little or no response to bronchodilator therapy (Table I). Their ages ranged from 50 to 72 (mean 62). All were smokers or ex-smokers. All had chronic cough with sputum (on most days for at least three months of the year, for at least two years) and in all the main complaint was of breathlessness. None had a family or personal history suggestive of atopy. Routine blood counts did not show an excess of eosinophils. Five had radiographic evidence of emphysema. No patient had electrocardiographic evidence of right ventricular hypertrophy. None had previously received steroid therapy. One subject only was receiving bronchodilator treatment (oral orciprenaline), and he continued this throughout the trial. No courses of antibiotics were required during the trial. 
T A B L E I

RESULTS OF INITIAL ('PRE-TRIAL') LUNG FUNCTION TESTING IN 10 SUBJECTS

\begin{tabular}{|c|c|c|c|c|c|c|c|c|c|c|c|}
\hline \multirow[b]{2}{*}{ Subject } & \multirow[b]{2}{*}{$\underset{\text { (1.) }}{\text { FEV }_{1}}$} & \multirow[b]{2}{*}{$\begin{array}{c}\text { FVC } \\
\text { (1.) }\end{array}$} & \multirow{2}{*}{$\begin{array}{c}\text { Predicted } \\
\text { VC } \\
\text { (1.) }\end{array}$} & \multirow{2}{*}{$\begin{array}{c}\text { FEV }_{1} / \\
\text { FVC } \\
\%\end{array}$} & \multicolumn{2}{|c|}{$\begin{array}{l}\text { Change after } \\
\text { Bronchodilator }\end{array}$} & \multirow{2}{*}{$\underset{\substack{\left.\mathrm{CmH}_{2} \mathrm{O} \\
\text { per } \\
1 / \mathrm{sec}\right)}}{\operatorname{Raw}}$} & \multirow{2}{*}{$\begin{array}{c}\text { SGaw } \\
(\mathrm{cm} \\
\mathrm{H}_{2} \mathrm{O}^{-1} \\
\left.\mathrm{sec}^{-1}\right)\end{array}$} & \multirow[b]{2}{*}{$\underset{(\mathbf{m m H g})}{\mathrm{PaO}_{2}}$} & \multirow[b]{2}{*}{$\underset{\left(\mathrm{mmHg}_{\mathbf{g}}\right)}{\mathrm{PacO}_{\mathbf{2}}}$} & \multirow[b]{2}{*}{ pH } \\
\hline & & & & & $\begin{array}{c}\text { in } \mathrm{FEV}_{1} \\
\text { (1.) }\end{array}$ & $\begin{array}{c}\text { in } \mathbf{F V C} \\
\text { (1.) }\end{array}$ & & & & & \\
\hline $\begin{array}{r}1 \\
2 \\
3 \\
4 \\
5 \\
6 \\
7 \\
8 \\
9 \\
10\end{array}$ & $\begin{array}{l}0.76 \\
1.53 \\
1.45 \\
1.17 \\
1.30 \\
0.50 \\
0.98 \\
1.68 \\
0.55 \\
1 \cdot 15\end{array}$ & $\begin{array}{l}1.94 \\
2.05 \\
3.38 \\
2.21 \\
2.08 \\
1.45 \\
1.93 \\
2.58 \\
1.88 \\
3.33\end{array}$ & $\begin{array}{l}4 \cdot 08 \\
4 \cdot 50 \\
4 \cdot 40 \\
4 \cdot 10 \\
4 \cdot 28 \\
4 \cdot 15 \\
3 \cdot 80 \\
4 \cdot 30 \\
3 \cdot 81 \\
4 \cdot 28\end{array}$ & $\begin{array}{l}39 \\
74 \\
43 \\
53 \\
63 \\
34 \\
51 \\
65 \\
29 \\
35\end{array}$ & $\begin{array}{r}-\overline{0.18} \\
+0.10 \\
+0.07 \\
-0.03 \\
+0.23 \\
-\overline{0.08} \\
+0.13 \\
+0.18\end{array}$ & $\begin{array}{r}\overline{0} \\
+0.23 \\
-0.10 \\
-0.01 \\
-0.15 \\
+0.75 \\
+\overline{0.08} \\
+0.30 \\
+0.27\end{array}$ & $\begin{array}{l}2 \cdot 9 \\
2 \cdot 3 \\
5 \cdot 5 \\
2 \cdot 0 \\
4 \cdot 8 \\
4 \cdot 2 \\
3 \cdot 6 \\
2 \cdot 9 \\
2 \cdot 7 \\
3 \cdot 1\end{array}$ & $\begin{array}{l}0.039 \\
0.071 \\
0.027 \\
0.078 \\
0.042 \\
0.029 \\
0.056 \\
0.059 \\
0.059 \\
0.047\end{array}$ & $\begin{array}{l}52 \\
68 \\
67 \\
96 \\
70 \\
70 \\
\\
79 \\
76\end{array}$ & $\begin{array}{l}52 \\
35 \\
47 \\
36 \\
43 \\
48 \\
46 \\
43 \\
54 \\
46\end{array}$ & $\begin{array}{l}7 \cdot 40 \\
7 \cdot 47 \\
7 \cdot 45 \\
7 \cdot 42 \\
7 \cdot 42 \\
7 \cdot 41 \\
7 \cdot 43 \\
7 \cdot 42 \\
7 \cdot 39 \\
7 \cdot 40\end{array}$ \\
\hline
\end{tabular}

Normal values for Raw and SGaw in our laboratory fall within the limits quoted by Cotes (1965), namely 0.5-2.0 $\mathrm{cmH}_{2} \mathrm{O}$ per $1 / \mathrm{sec}$, and 0.13$0.35 \mathrm{~cm} \mathrm{H}_{2} \mathrm{O}^{-1} \mathrm{sec}^{-1}$ respectively. Predicted VC is taken from Cotes's nomogram (1965). Means and standard deviations are shown in Table II.

\section{METHODS}

The trial was conducted over the months January to April. Each patient took $2.5 \mathrm{mg}$ prednisone twice daily for a week, and placebo tablets for a week, the order of administration being randomized and known only to the hospital pharmacist. Five subjects took placebo in the first week and prednisone in the second week and the other five took their tablets in the reverse order.

The lung function studies were carried out on three occasions, first immediately before starting the trial ('pre-trial') and again after the first and second weeks of treatment ('placebo' or 'prednisone').

The following measurements were made, in the same order, at each attendance, between 14.00 and 16.00 hours.

1. FORCED EXPIRATORY VOLUMES We measured forced expiratory volumes in 1 second $\left(F E V_{1}\right)$, forced vital capacity (FVC), and the $\mathrm{FEV}_{1} / \mathrm{FVC}$ ratio with a dry spirometer (Collins, McDermott, and McDermott, 1964), obtained three technically satisfactory blows at approximately one minute intervals, and took the mean of the highest two values for each variable.

2. INSPIRATORY AIRWAYS RESISTANCE (RaW) AND SPECIFIC CONDUCTANCE (SGaw) We used a constant volume whole body plethysmograph (Dubois et al., 1956a; Dubois, Botelho and Comroe, 1956b) with the patient in the semi-reclining position. Thoracic gas volume (TGV) was measured by the airway occlusion technique. The relation between alveolar pressure and flow was displayed on a storage oscilloscope (Tektronix 564B). Slope measurements for derivation of Raw were made on the inspiratory portion of the trace, the expiratory phase being widely looped in these patients. The means of three measurements of TGV and of Raw were taken, and SGaw was calculated as the conductance, or reciprocal of Raw, divided by TGV.

3. RESPONSE TO ISOPRENALINE When the above measurements were completed the patient received two inhalations of isoprenaline aerosol from a metereddose container (Medihaler Iso Forte) and the measurements of $F E V_{1}, F V C$, and $F E V_{1} / F V C$ were repeated. Two patients ( 1 and 7 ) declined this part of the procedure because of previous side effects from similar therapy.

4. BLOOD GAS ANALySis Finally, a sample of blood was taken under local anaesthesia from the brachial artery and analysed for the partial pressure of oxygen $\left(\mathrm{PaO}_{2}\right)$, carbon-dioxide $\left(\mathrm{PaCO}_{2}\right)$, and $\mathrm{pH}$ with Radiometer electrodes. $\mathrm{PaO}_{2}$ measurements were not obtained in patients 7 and 8 .

RADIOLOGICAL ASSESSMENT The chest radiographs of all subjects were examined by an independent observer (Dr. J. W. Pierce) and assessed for the presence of emphysema with particular reference to the nature of peripheral vascular markings (Laws and Heard, 1962). The films were divided into three groups: (1) no evidence of emphysema; (2) probable evidence of emphysema; and (3) definite emphysema. Each film was assessed on two separate occasions, the observer being unaware of the results of lung function tests and, during the second assessment, of his previous grading of the film. In fact the only two patients initially graded as 'probable' (5 and 9) were on the second occasion thought to show no evidence of emphysema and have been graded as such. The other eight films were given the same grading on both occasions.

\section{RESULTS}

Table I shows the initial lung function assessment for each patient. All had clear evidence of airways obstruction of varying degree. Bronchodilator response was unimpressive (although useful in subject 6), and did not in any patient restore spirometric values to anywhere near normal. If the upper limit of normal $\mathrm{PaCO}_{2}$ is set at $45 \mathrm{mmHg}$, six patients had mild respiratory failure with $\mathrm{CO}_{2}$ retention.

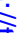
으 $\dot{0}$ in. 3 옥 궁 N S 은 $\stackrel{\mathbb{D}}{\longrightarrow}$ 7 뭉 $\frac{\vec{D}}{\stackrel{9}{\mathbb{D}}}$ 
The effects of prednisone and placebo on lung function are shown in Table II. No significant differences were seen in forced expiratory volumes, bronchodilator effect on forced expiratory volumes, or blood gases. Inspiratory resistance was significantly higher (i.e., worse) and specific conductance lower on prednisone than on placebo (Fig. 1). This was also true if the prednisone measurements are compared with those immediately before prednisone treatment ('pre-trial' in five cases and 'placebo' in five). The statistical

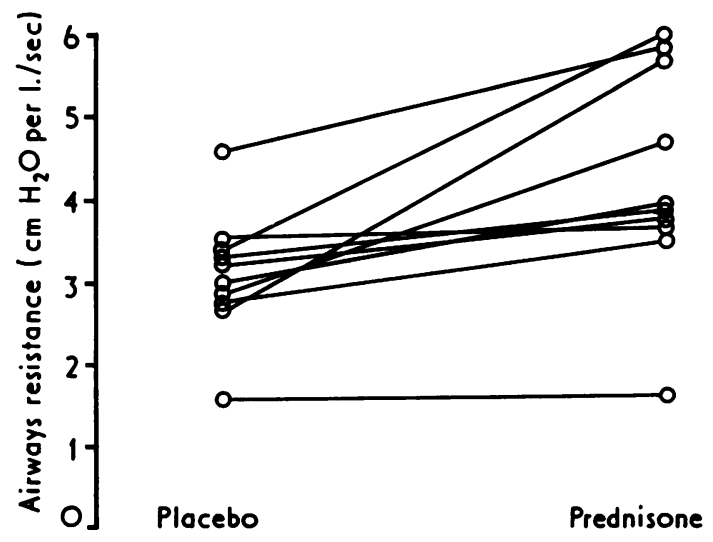

(a)

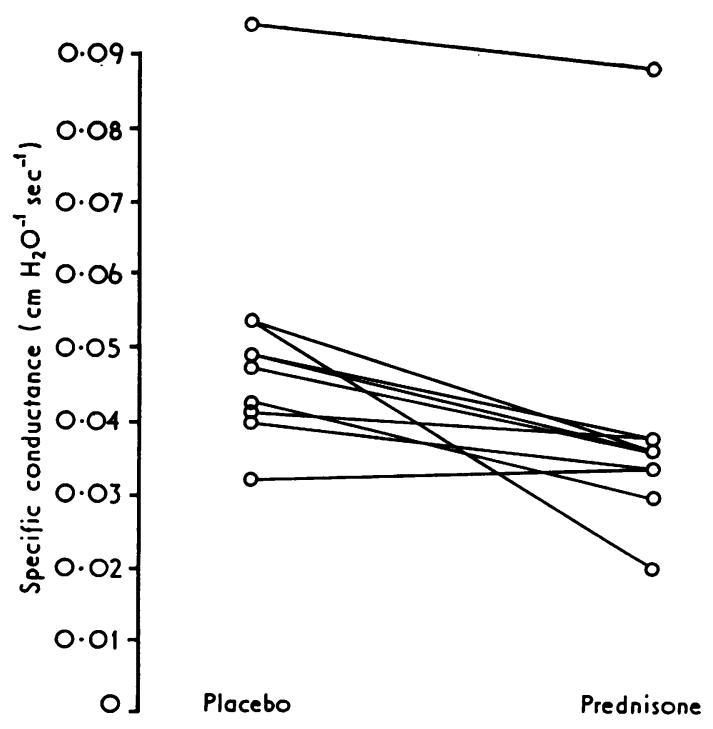

(b)

FIG. 1. Measurements of (a) Raw and (b) SGaw on prednisone and placebo tablets. significance of the changes in Raw on prednisone is mainly due to large changes in two patients, 4 and 7. No particular characteristics otherwise distinguished them from the group as a whole.

Since the subjects had fortuitously fallen into two equal groups with and without evidence of emphysema on the chest film, they were tested for differences between means for each group, for all variables described above, using an unpaired twotailed $t$ test. No significant differences were found.

\section{DISCUSSION}

Whole body plethysmography provides a sensitive method of detecting small changes in airways resistance (Lloyd and Wright, 1963; Stein, Tanabe, Rege, and Khan, 1966). Since intrathoracic airways become wider on inspiration and narrower on expiration, the value for Raw obtained depends on the lung volume at which the measurement is made. We measured thoracic gas volume and found no significant differences in mean values on the three occasions of measurement. Hence these three measurements of airways resistance may fairly be compared. Since the relation between conductance (1/Raw) and thoracic gas volume is roughly linear (Briscoe and Dubois, 1958) many workers prefer to express their results as specific conductance, that is, conductance divided by the thoracic gas volume at which the measurement was made, in an attempt to obtain an index independent of lung volume. This assumes not only linearity of the conductance (TGV relation) but also that it passes through zero, which is not quite true for normal subjects (Briscoe and Dubois, 1958) and probably less so for patients with chronic lung disease. Detailed figures for Raw, SGaw, and TGV on placebo and prednisone are given in Table III. In all except one patient (4) the maximum variation in $\mathrm{TGV}$ was 0.71 . In patient 4 a large increase in airways resistance occurred on prednisone despite an increase of 2.21 . in TGV (which if acting alone would have been expected to be accompanied by a fall in resistance). In this patient also, $F_{E V}$ fell on prednisone from 0.97 to 0.68 , and FVC from 2.39 to 1.50 1. Surprisingly, $\mathrm{PaO}_{2}$ in this patient was the highest in the group: $96 \mathrm{mmHg}$ pre-trial, $100 \mathrm{mmHg}$ placebo, $96 \mathrm{mmHg}$ prednisone. $\mathrm{PaCO}_{2}$ was $36 \mathrm{mmHg}$ on all three occasions. He was aged 69 , a smoker, had a 30-year history of chronic cough and sputum, and radiographic evidence of emphysema.

While we have expressed our results both as Raw and SGaw, the changes in one closely 
T A B L E I I

MEAN RESULTS, WITH 1 STANDARD DEVIATION, FOR LUNG FUNCTION TESTS

\begin{tabular}{|c|c|c|c|c|c|}
\hline & \multirow[b]{2}{*}{ Pre-trial } & \multirow[b]{2}{*}{ Prednisone } & \multirow[b]{2}{*}{ Placebo } & \multicolumn{2}{|c|}{ Comparisons } \\
\hline & & & & $\begin{array}{c}\text { Placebo } v \\
\text { Prednisone }\end{array}$ & $\begin{array}{c}\text { Before } v \text { after } \\
\text { Prednisone }\end{array}$ \\
\hline $\begin{array}{l}\text { FEV }_{1}(1 .) \\
\text { FVC (l.) } \\
\left.\text { FEV }_{1} / \text { FVC ( } \%\right)\end{array}$ & $\begin{array}{l}1 \cdot 11(0 \cdot 40) \\
2 \cdot 28(0 \cdot 63) \\
49(15)\end{array}$ & $\begin{array}{l}0.99(0.37) \\
2.20(0.54) \\
46(16)\end{array}$ & $\begin{array}{l}1 \cdot 03(0 \cdot 37) \\
2 \cdot 22(0 \cdot 66) \\
47(16)\end{array}$ & $\begin{array}{l}\text { NS } \\
\text { NS } \\
\text { NS }\end{array}$ & $\begin{array}{l}\text { NS } \\
\text { NS } \\
\text { NS }\end{array}$ \\
\hline $\begin{array}{l}\text { Change after } \\
\text { bronchodilator } \\
\text { in FEV } 1 \text { (1.) } \\
\text { in FVC (1.) }\end{array}$ & $\begin{array}{l}+0.09(0.13) \\
+0.17(0.28)\end{array}$ & $\begin{array}{l}+0.15(0.13) \\
+0.19(0.29)\end{array}$ & $\begin{array}{l}+0.10(0.13) \\
+0.17(0.36)\end{array}$ & $\begin{array}{l}\text { NS } \\
\text { NS }\end{array}$ & $\begin{array}{l}\text { NS } \\
\text { NS }\end{array}$ \\
\hline $\begin{array}{l}\left.\text { Raw (cmH } \mathrm{Cm}_{2} \mathrm{O}_{\mathrm{per}} 1 / \mathrm{sec}\right) \\
\text { SGaw }\left(\mathrm{cmH}_{2} \mathrm{O}^{-1} \mathrm{sec}^{-1}\right)\end{array}$ & $\begin{array}{l}3 \cdot 38(1 \cdot 12) \\
0.051(0.016)\end{array}$ & $\begin{array}{r}4.24(1.33) \\
0.039(0.018)\end{array}$ & $\begin{array}{l}3.19(0.77) \\
0.050(0.016)\end{array}$ & $\begin{array}{l}0<2 \mathrm{P}<0.02 \\
0<2 \mathrm{P}<0.01\end{array}$ & $\begin{array}{l}0<2 \mathrm{P}<0.02 \\
0<2 \mathrm{P}<0.01\end{array}$ \\
\hline $\begin{array}{l}\mathrm{PaO}_{2}(\mathrm{mmHg}) \\
\mathrm{PaCO}_{2}(\mathrm{mmHg}) \\
\mathrm{pH}\end{array}$ & $\begin{array}{l}72(12) \\
45(6) \\
7.42(0.02)\end{array}$ & $\begin{array}{l}74(11) \\
47(7) \\
7.41(0.02)\end{array}$ & $\begin{array}{l}74(11) \\
47(6) \\
7.42(0.01)\end{array}$ & $\begin{array}{l}\text { NS } \\
\text { NS } \\
\text { NS }\end{array}$ & $\begin{array}{l}\text { NS } \\
\text { NS } \\
\text { NS }\end{array}$ \\
\hline
\end{tabular}

Comparisons between means are made by a two-tailed paired $t$ test. In the 'before $v$ after prednisone' comparison the results on prednisone are compared with the results immediately preceding the prednisone week-'placebo' in five cases, and 'pre-trial' in five cases. NS= not significant $(2 \mathrm{P}>0.05)$.

T A B L E I I I

INDIVIDUAL VALUES FOR FEV, FVC, Raw, SGaw, AND TGV FOR 10 SUBJECTS ON PLACEBO AND PREDNISONE

\begin{tabular}{|c|c|c|c|c|c|c|c|c|c|}
\hline \multicolumn{2}{|c|}{$\mathrm{FEV}_{1}$ (1.) } & \multicolumn{2}{|c|}{ FVC (1.) } & \multicolumn{2}{|c|}{$\mathrm{Raw}\left(\mathrm{cmH}_{2} \mathrm{O}\right.$ per $\left.1 / \mathrm{sec}\right)$} & \multicolumn{2}{|c|}{ SGaw $\left(\mathrm{cmH}_{2} \mathrm{O}^{-1} 1 / \mathrm{sec}\right)$} & \multicolumn{2}{|c|}{ TGV (1.) } \\
\hline Placebo & Prednisone & Placebo & Prednisone & Placebo & Prednisone & Placebo & Prednisone & Placebo & Prednisone \\
\hline $\begin{array}{l}0.66 \\
1.62 \\
1.35 \\
0.97 \\
1.18 \\
0.65 \\
0.85 \\
1.52 \\
0.55 \\
0.98\end{array}$ & $\begin{array}{l}0.72 \\
1.53 \\
1.22 \\
0.68 \\
1.20 \\
0.73 \\
0.78 \\
1.53 \\
0.50 \\
1.08\end{array}$ & $\begin{array}{l}1.87 \\
2.23 \\
3.93 \\
2.39 \\
1.95 \\
2.15 \\
1.48 \\
2.35 \\
1.95 \\
1.91\end{array}$ & $\begin{array}{r}2.09 \\
2.25 \\
3.42 \\
1.50 \\
1.78 \\
2.18 \\
2.18 \\
2.28 \\
1.70 \\
2.67\end{array}$ & $\begin{array}{l}2.9 \\
1.6 \\
3.4 \\
2.8 \\
4.6 \\
3.0 \\
3.4 \\
3 \cdot 1 \\
3.4 \\
3.6\end{array}$ & $\begin{array}{l}3.6 \\
1.6 \\
3.8 \\
5 \cdot 7 \\
5 \cdot 8 \\
4 \cdot 2 \\
6.1 \\
3.9 \\
3.8 \\
3.8\end{array}$ & $\begin{array}{l}0.049 \\
0.094 \\
0.041 \\
0.054 \\
0.047 \\
0.042 \\
0.054 \\
0.049 \\
0.040 \\
0.033\end{array}$ & $\begin{array}{l}0.036 \\
0.089 \\
0.037 \\
0.020 \\
0.036 \\
0.030 \\
0.036 \\
0.038 \\
0.034 \\
0.034\end{array}$ & $\begin{array}{l}7 \cdot 04 \\
6 \cdot 65 \\
7 \cdot 12 \\
6 \cdot 61 \\
4 \cdot 63 \\
7.94 \\
5 \cdot 29 \\
6 \cdot 58 \\
7 \cdot 35 \\
8 \cdot 41\end{array}$ & $\begin{array}{l}7 \cdot 72 \\
7 \cdot 02 \\
7 \cdot 11 \\
8 \cdot 78 \\
4 \cdot 78 \\
7 \cdot 93 \\
4 \cdot 55 \\
6 \cdot 75 \\
7 \cdot 74 \\
7 \cdot 74\end{array}$ \\
\hline
\end{tabular}

followed changes in the other in individual patients, reflecting the fact that TGV was very similar on all three occasions when it was measured (with the one exception already mentioned). We include figures for SGaw to allow comparison with the results of others (Oppenheimer, Rigatto, and Fletcher, 1968).

Previous studies of the effect of prednisone in chronic airways obstruction have given variable, and generally discouraging, results. Earlier studies (Franklin, Michelson, Lowell, and Schiller, 1958; Corazza, Morrow, and Chesney, 1961; Clifton and Stuart-Harris, 1962; Freedman, 1963; Fuleihan, Feisal, and Malouf, 1967) were not controlled. Moyes and Kershaw (1957) concluded that there was no significant symptomatic benefit to chronic bronchitics given tetracycline plus prednisone, $15 \mathrm{mg} / \mathrm{day}$, as opposed to tetracycline alone. Lung function studies were limited to vital capacity measurements. Oppenheimer et al. (1968), in a controlled single-blind study using body plethysmography, found no significant benefit in patients given $20 \mathrm{mg}$ prednisone for one week. Their patients had a mean $\mathrm{FEV}_{1}$ of 1.471 , mean VC of 2.911 , and mean SGaw of $0.103 \mathrm{cmH}_{2} \mathrm{O}^{-1} \mathrm{sec}^{-1}$, suggesting that, as a group, they had less severe obstruction than ours (mean $\mathrm{FEV}_{1} 1 \cdot 11$ 1., FVC 2.28 1., SGaw $0.051 \mathrm{cmH}_{2} \mathrm{O}^{-1} \mathrm{sec}^{-1}$ in the pre-trial values). Indeed their mean value for SGaw of 0.103 falls not far below the lower limit of normal $(0 \cdot 13)$ obtained by Briscoe and Dubois (1958), with which observations in our laboratory agree.

There appear to be only three double-blind trials other than our own. Beerel, Jick, and Tyler (1963) did not use body plethysmography and gave prednisone in high dosage $(60 \mathrm{mg}$ daily, decreasing to $20 \mathrm{mg}$ on the third day, and continuing at that dose for two weeks in all). Marked improvement in FEV, was seen in two patients, but both had had episodes of wheezing since adolescence, which suggested an asthmatic basis for their symtoms. Beerel and Vance (1971) showed some improvement in arterial blood gases and pulmonary diffusing capacity in patients with emphysema given $60 \mathrm{mg}$ prednisone daily initially, decreasing to a maintenance dose of $20 \mathrm{mg}$ daily for eight weeks. 
Seven of the 23 patients in this study had obvious side effects of steroids. Morgan and Rusche (1964) did use body plethysmography in five of seven subjects, and gave betamethasone, $3.6 \mathrm{mg}$ daily for three days, and $1.8 \mathrm{mg}$ daily thereafter, equivalent to 24 and $12 \mathrm{mg}$ prednisone respectively. All five patients showed deterioration in measurements of airways resistance while on the active preparation, not only on body plethysmography but also in measurements derived from spirometry. We have now reached a similar conclusion giving only $5 \mathrm{mg}$ prednisone daily.

We did not systematically investigate symptoms. All patients said they 'felt better' on the tablets but, more to the point, did not distinguish between placebo and active treatment.

It may have been assumed in the past that if steroids, in low dose, were given to patients with chronic airways obstruction, they would do no harm, even if they did no good. Our findings, in conjunction with those of Morgan and Rusche (1964), suggest that this is not always the case.

It may be very difficult to distinguish clinically between a patient with chronic bronchitis, airways obstruction, and increasing dyspnoea, and a patient with chronic bronchitis and late-onset asthma. In such cases a trial of steroids may be justified. Clearly, the result of such a trial should be judged by careful and detailed assessment of lung function.

We are glad to record the assistance of $\mathrm{Mr}$. Coles (Hospital Pharmacy), who controlled the randomization of the trial, and of Miss Valerie Arnold (Department of Clinical Physiology) who did the blood gas measurements. Dr. J. W. Pierce graded the chest radiographs and Dr. M. Webb-Peploe assessed the electrocardiagrams.

The body plethysmograph was purchased by a grant from the St. Thomas' Hospital Endowments Committee and built by Vickers Ltd. (Medical Group), to whom we are indebted for advice and servicing facilities.

\section{REFERENCES}

Beerel, F., Jick, H., and Tyler, J. M. (1963). A controlled study of the effect of prednisone on air-flow obstruction in severe pulmonary emphysema. New England Journal of Medicine, 268, 226.

Beerel, F. R. and Vance, J. W. (1971). Prednisone treatment for stable pulmonary emphysema. American Review of Respiratory Disease, 104, 264.

Briscoe, W. A. and Dubois, A. B. (1958). The relationship between airway resistance, airway conductance and lung volume in subjects of different age and body size. Journal of Clinical Investigation, 37, 1279.

Clifton, M. and Stuart-Harris, C. H. (1962). Steroid therapy in chronic bronchitis. Lancet, 1, 1311.

Collins, M. M., McDermott; M., and McDermott, T. J. (1964). Bellows spirometer and transistor timer for the measurement of forced expiratory volume and vital capacity. Journal of Physiology, 172, 39P.

Corazza, L. J., Morrow, C. S., and Chesney, T. A. (1961). Triamcinolone in the therapy of chronic bronchitis and pulmonary emphysema. American Journal of Medical Science, 242, 436.

Cotes, J. E. (1965). Lung Function, Chapter 14. Blackwell Scientific Publications, Oxford.

Dubois, A. B., Botelho, S. Y., Bedell, G. N., Marshall, R., and Comroe J. H. (1956a). A rapid plethysmographic method for measuring thoracic gas volume: a comparison with a nitrogen washout method for measuring functional residual capacity in normal subjects. Journal of Clinical Investigation, 35, 322.

- - - and Comroe, J. H. (1956b). A new method for measuring airway resistance in man using a body plethysmograph; values in normal subjects and in patients with respiratory disease. Journal of Clinical Investigation, 35, 327.

Evans, J. A., Morrison, I. M., and Saunders, K. B. (1973). Double blind trial of prednisone, in low dose, in patients with chronic airways obstruction. Clinical Science, 44, 26P.

Franklin, W., Michelson, A. L., Lowell, F. C., and Schiller, I. W. (1958). Bronchodilators and corticosteroids in the treatment of obstructive pulmonary emphysema. New England Journal of Medicine, 258, 774.

Freedman, B. J. (1963). Bronchodilators and corticosteroids in chronic bronchitis and emphysema. British Medical Journal, 2, 1509.

Fuleihan, F. J. D., Feisal, K. A., and Malouf, N. N. (1967). Effect of corticosteroids on pulmonary function in chronic bronchitis with airway obstruction. American Review of Respiratory Disease, 96, 678.

Laws, J. W. and Heard, B. E. (1962). Emphysema and the chest film: a retrospective radiological and pathological study. British Journal of Radiology, 35, 750 .

Lloyd, T. C. Jr. and Wright, G. W. (1963). Evaluation of methods used in detecting changes of airways resistance in man. American Review of Respiratory Diseases, 87, 529.

Morgan, W. K. C. and Rusche, E. (1964). A controlled trial of the effect of steroids in obstructive airway disease. Annals of Internal Medicine, 61, 248.

Moyes, E. N. and Kershaw, R. A. (1957). Longcontinued treatment with tetracycline and prednisolone in chronic bronchitis: a controlled trial. Lancet, 2, 1187. 
Oppenheimer, E. A., Rigatto, M., and Fletcher, C. M. (1968). Airways obstruction before and after isoprenaline, histamine, and prednisolone in patients with chronic obstructive bronchitis. Lancet, 1, 552.

Stein, M., Tanabe, G., Rege, V., and Khan, M. (1966). Evauluation of spirometric methods used to assess abnormalities in airway resistance. American Review of Respiratory Diseases, 93, 257.

Requests for reprints to: Dr. J. A. Evans, University College Hospital, Gower Street, London WC1. 